\title{
HORACE BUSHNELL AND ALBRECHT RITSCHL.
}

\author{
A COMPARISON.
}

By GEORGE B. STEVENS, New Haven, Conn.

THE object of this paper is to show to what an extent Bushnell marked out lines of theological method and thought which coincide substantially with the movements of recent opinion. For this purpose I shall bring his views into comparison with those of the modern German schools, especially with Ritschlianism. Two men could hardly be more unlike than were Bushnell and Ritschl ; yet the affinity between their theological results is really striking. Ritschl was a professional, systematic theologian-a man who spent his life in universities, studying. teaching, and elaborating a system of theological thought. Bushnell was not primarily a student of theology; he was a preacher, a solitary thinker, and, withal, a religious genius. Ritschl was somewhat cold and severe in temperament and method, wrote in a heavy, academic style, and spent the greater part of his life in elaborating one great work on the Christian doctrine of salvation, in three stout volumes. Bushnell, on the other hand, was intense and, at times, almost vehement in feeling, was the master of one of the most original and versatile of styles, and was accustomed to publish the results of his thinking whenever he felt that he had a message, with little concern for system or even strict consistency. The two thinkers stood im no direct relation. Bushnell can hardly be said to have been a student of German theology; even less, however, was Ritschl a student of American. When Ritschl's great theological work was published, Bushnell was nearing his end. All his theological books, except Forgiveness and Law, antedated Ritschl's treatise on Justification and Reconciliation. The Ritschlian movement has attracted marked attention in England and America only within the last decade.

The points of connection between Bushnell and Ritschl were 
(I) a certain kinship of spirit and method in theology, and (2) some use of common sources. In the first place, both insisted that Christianity was a religion and not a system of transcendental metaphysics, and both sought to interpret the New Testament and Christian history in accord with this presupposition. As to the second point, the spirit of Schleiermacher entered largely into the thought of both men. Bushnell, indeed, knew the great champion of the rights and demands of the religious consciousness only through fragments of translation, and second hand ; for Ritschl the principle of the supremacy of ethical and religious convictions and judgments in the sphere of faith was absolutely fundamental.

There is a certain advantage and a special interest in comparing thinkers who have never stood in any personal relation, whose history has been widely different, but whose results are, in important respects, similar. There is one point, however, in which the experience of the two men in question was alike. Both represent a reaction against the current methods and results in the dogmatics of their time; both, also, represent a recoil from the religious indifferentism and arid rationalism into which many had fallen in reaction from traditional orthodoxy. Both men made honest attempts to deepen the religious convictions of their contemporaries. Both were advocates of religion as the supreme interest of life, and whatever subtractions they made from the current theology were made in the belief that the interests of religion demanded the changes of view proposed. Both men met with abundant opposition to their opinions, and that from both sides-the conservative and the radical. Bushnell was set upon by Puritan orthodoxy and barely escaped trial for heresy; Ritschl was attacked by Lutheran orthodoxy as compromising with dangerous tendencies, while professing to champion evangelical views. The Unitarians did not think more favorably of the consistency of Bushnell than the neo-Hegelians did of the tenableness of Ritschl's middle position.

In the comparison which is to follow I disclaim in advance the making out of any formal similarity in method or precise 
identity in results between Bushnell and modern theology. What I wish to exhibit is the inner affinity, the points of contact in the practical outcome of the two movements. I shall consider four points: (I) the limitations of theological knowledge, (2) the Trinity, (3) the person of Christ, and (4) the doctrine of atonement.

Bushnell wrought out his theory of the limitations of theological knowledge in his essay on language. His contention was that all terms which are applied to thought or spirit, being. based on physical analogy, are inadequate to express the full import of any theological truth. All the words which we apply to God, the soul, and their relations are figurative; they are signs and images, not absolute measures and equivalents of spiritual truths. There is a formal element in all the words which are applied to spirit which theologians are wont to make too much of in their theories and arguments, spinning out whole series of inferences from the logical forms of certain words. This procedure misconceives the very nature of language, which is made up of signs or hints, not of formally precise and adequate expressions for the spiritual facts. "Words of thought or spirit are earthen vessels in which the truth is borne, yet always offering their mere pottery as being the truth itself" (God in Christ, p. 48). Hence the necessary imperfection of all theological definitions. They are made up of figurative and inadequate symbols; yet theologians often regard and apply them as though they were as scientifically exact as the axioms and processes of mathematics. Bushnell instances the discussions and definitions of the action of the will in which writers are commonly "overpowered by the terms and predicates of language, which, being. mostly derived from the physical world, are charged, to the same extent, with a mechanical significance" (God in Christ, p. 62). From this source proceeds the futile discussion of what causes the choices of the will, whereas, in fact, the real problem is one of spirit to which the analogical words in use can have no application.

Such considerations led Bushnell to place a low estimate on formal logical argumentations in theology, in comparison with 
spiritual insight. He complained that, too often, theologians were "mere logickers," "one-word professors quarreling with everyone who goes out of their word." His contention was against those who "make a given word a law to their thinking," building a lofty superstructure of inference upon some human analogy, such as government, decree, substitution. Bushnell did not advocate the abandonment of such terms; we could not abandon them if we would. We have no other medium than this figurative language. His contention was, however, that these thought-forms must not be identified with the truth, or be regarded as exactly and exclusively descriptive of it. $\mathrm{He}$ claimed that the Bible, instead of using the approved method of definition, gives us the truth in a great variety of forms, many of which, if treated on the scholastic's method, would be contradictory enough. Scripture uses pictorial language in accordance with its nature in order, by appeal to our varied powers and faculties, to quicken in us the sense of God and of spiritual things. Here we see the living use and power of language in contrast to the cut and dried pre-cision ("the cutting up of the body of truth into definite and dead morsels," God in Christ, p. 93) which is illustrated in "scientific" theology. Bushnell's argument reminds one of the saying of Hase: "Die Dogmatik ist ein Herbarium, d. h., eine systematisch wohlgeordnete Samm. lung getrockneter Pflanzen; in der Heiligen Schrift lebt noch der unvergängliche Frühling." The practical object of Bushnell was to support the conclusion that "language under the laws of logic or speculation does not seem to be adequate" to provide us with "a satisfactory and truly adequate system of scientific theology" (God in Christ, p. 77).

Bushnell's discussion of the nature of language, as applied to spiritual subjects, is very interesting and suggestive, and supplies an important corrective to ordinary theological procedure. Who does not recall illustrations of the bondage of physical analogy in theology against which Bushnell inveighed? Atonement explained in terms of military operations - in terms of commercial transactions - in terms of human government; the doctrine of salvation defined exclusively in terms of a legal analogy; 
and so on throughout the whole range of doctrine. Bushnell did a good work for theology in this essay, reminding it of its true nature as a philosophy of a spiritual world and protesting against the idea that the mysteries of God's being and providence could be explained by definition and logical deduction.

But it is obvious that Bushnell's discussion did not go to the heart of the problem of the nature and limits of theological knowledge. His was a theory concerning the instrument of thought, rather than of thought itself. He set limits to theology by insisting that it employed a defective medium. What is chiefly needed, however, is a theory of the knowable, not merely of the expressible. It is this which every philosophic theologian undertakes to furnish. Let us note the salient points in the Ritschlian view.

Ritschl built his theory of knowledge upon the principles of Kant. He regarded all the speculative arguments for the being of God and the religious view of the world as more or less ineffective, and set a low estimate upon natural theology as a whole. Indeed, Ritschl placed a relatively low value upon philosophical speculation as an aid to religious belief. $\mathrm{He}$ pointed to the effects of metaphysics-Platonic, Alexandrian, Hegelian-upon theology, and asked whether these systems have helped or harmed the cause with which they were allied.

But if Ritschl is skeptical concerning the speculative defense of faith, he is positive concerning its moral basis in human nature. Religion has its ground in the religious constitution of man-in that world of values and ends to which man knows that he belongs and whose existence he will never consent to stake upon any scheme of theoretic reasoning. Hence faith has its rights and does not need to hinge its raison d'être upon any of the contending philosophical systems. If theology must wait till some generally accepted system of metaphysics is adopted, it would better withdraw from the field and resign its task.

Ritschl's view is, then, that the mind of man is wholly incompetent to construct an adequate theoretic system of the universe. All his logical processes and speculative arguments cannot prove the being of God; much less, his goodness and 
forgiving mercy. The existence of God is a practical, moral conviction which the heart and conscience of man demand-a value-judgment, that is, a belief required by the religious nature of man. It is not on this account less certain, but more certain. The verdicts of the moral reason are our highest certainties. Our ethical convictions are more secure than our theoretic processes, because they are the utterances of what we know to be highest in us - the convictions which give worth to life. Moral value is the highest test of truth. All religious certitude is based upon it. Religious beliefs are not conclusions demonstrated from premises and axioms as the mathematician's result is demonstrated. They are of a different nature; they are not mere cold, disinterested, theoretic judgments; they are ethical and religious judgments, "judgments of value," as Ritschl calls them, verdicts of our higher nature. But they are not less trustworthy than mere theoretical knowledge because they are different in their nature. Indeed, they have their own advantage, because they are the verdicts of the highest court.

Now, this method of setting limits to religious thought is obviously very different from Bushnell's; yet the two schemes have their affinities and issue in a very similar practical result. Both go to show that a fully rounded system of speculative theology is quite impossible; both lay strong emphasis upon the religious, as contrasted with the merely logical and theoretic, character of theological knowledge. Bushnell's contention was that religious truth could not find adequate expression in human language; Ritschl goes farther back and seeks to define the nature and limitations of our knowledge of religious truth. But this was what Bushnell was feeling after in his theory of language, and he frequently touches the problem in what he says of the rights of religious conviction and intuition as against the theoretic processes of speculative theology. ${ }^{x}$

\footnotetext{
"For example: "What they [the terms of religion] carry into our soul's feeling or perception, or awaken in it by expression, is their only truth" (Christ in Theology, p. 17). "Real truth is to be found only by insight, and never by the extempore clatter of logical judgments" (ibid., p. 22). He advocates a "suspension of our intensely dogmatizing habit," urging "how the ceasing to be busied about and upon truth, as a dead body offered to the scalpels of logic, and the giving ouselves to truth
} 
The next topic is the Trinity. Bushnell protested, in general, against the doctrine of the Trinity current in his time as a theorem unwarrantable alike on account of its presumptuousness and its inconsistency. If the Deity is defined as consisting of three persons, then we have not one God, but a family of Gods. If, on the other hand, theology shrinks from using the term "person," or explains it as meaning something less than a distinct self-consciousness and will, then the ground of historic orthodoxy is abandoned, and a modal theory of the Trinity is inevitable. This was Bushnell's own position. He held a modal Trinity, or, as he preferred to say, an "instrumental" Trinity; that is, he regarded the word "Trinity" as a term which designated the threefold aspect of God's historic self-revelation. $\mathrm{He}$ did not deny that, corresponding to this threefoldness in revelation, there might be immanent distinctions - aspects or principles - in God's being. Indeed, in his essay on "The Christian Trinity a Practical Truth (New Englander, November, I 854), he spoke of God's "eternally threeing himself." In general, however, and for all practical purposes, Bushnell correlated the idea of the Trinity with revelation. We can conceive

as set before us in living expression, under God's own forms, yielding them a pure heart in which to glass themselves, would fill us evermore with senses of God and his truth otherwise unattainable" (ibid., p. 32).

How closely this position resembles that of the French so-called "fideistic" school may be seen from the following characterization of it by Rev. J. D. Fleming in the Expository Times for June, 1901 : "The formal or philosophical principle which characterizes the school is the theory that religious thought, dealing, as it does, with the invisible, spiritual, and eternal, but having no adequate categories to express them, is obliged to clothe what is transcendent in sensible, material, phenomenal forms. The religious sentiment or idea incarnates itself in a local, contingent, concrete form which varies under the influence of prevailing scientific or philosophical ideas." This French school is closely akin to the Ritschlian movement. Among its distinguished representatives may be named the late Professors Bouvier of Geneva and Sabatier of Paris, and the present dean of the Paris faculty of Protestant theology, Dr. Ménégoz. The Life of Bouvier shows how, in the face of Genevan orthodoxy, he fought his way, very much as Bushnell did, to a new and independent position. The two men seem to me to have been much alike in many personal characteristics, as they certainly were in theological opinion. But Bouvier won more acceptance for his views in the very home of Calvin than Bushnell could do for his in New England, for he became professor of dogmatic theology in the university of Geneva, where for more than thirty years he devoted his genius to the reconstruction of theology. 
and use the idea in no other way. In what manner, possibly, the Infinite may be three, without ceasing to be one Person, we cannot know; and what we cannot know it cannot be useful to assert. We know God's threefold revelation; his inner mystery we do not know; it is not open to our inspection. Better to assert less than to assert what is self-contradictory.

Very similar is the position of Ritschl and his school, and, indeed, of many who do not confess themselves his disciples. The Ritschlian theologians regard the Trinity of the Nicene Creed as a product of Greek metaphysics - an effort of speculative thought to define the unknowable. It can have little, if any, religious value. Ritschl himself gives but very slight consideration to the subject. I will therefore cite the opinions of a few other theologians who illustrate, in general, the Ritschlian "tendency," and briefly compare their views with that of Bushnell.

Kaftan, professor in Berlin and a leading Ritschlian of the more conservative type, presents in his Dogmatik a view of the Trinity which I have condensed thus:

In the Christian knowledge that God is revealed in Christ, and imparted and indwelling by his Spirit, are given the elements of trinitarian belief. This belief has its roots in history and experience, and must be interpreted and estimated in accord with them. In revelation is disclosed an economic Trinity - a threefoldness of God's historic manifestation. But we must go farther. We must see in revelation, not only what God does, but something of what he is. The eternal is mirrored in the historical. We therefore say: The revelations in Christ and in the Spirit correspond to and express the eternal nature of God. Beyond some such general statement, however, we cannot go. The eternal background of the threefold revelation is undefinable. Dorner, Kaftan's predecessor, had advocated a Trinity of "principles" in God, repudiating the use of the term "person" as applied to them. In God, he held, there is but one person.

Lobstein, professor in Strassburg, another Ritschlian, also defines the Trinity from the historical point of view. In his Introduction to Theology (French and German, and untranslated), 
he says: The salvation provided by the wisdom and love of the heavenly Father, realized in the historic work of the Savior and communicated by the inner action of the Spirit, finds its most complete and profound expression in the trinitarian formula, which sums up the system of Christian dogmatic. He adds that the starting-point of the doctrine must be, not speculation, but revelation in Christ and in the Spirit, and that it is a truth of religion, distinctively. He contends that traditional orthodoxy has developed its trinitarian speculations too much from abstract views of the divine nature, instead of proceeding from effect to cause, from fact to idea. The Trinity which the New Testament presents is a religious, historic, economic Trinity; the orthodox doctrine is a speculative deduction produced by an unwarranted use of various analogies, physical, psychological, and mystical.

The late Professor Nitzsch, of Kiel, not a Ritschlian, holds that "Trinity" expresses three principles or potencies which appear in the divine self-revelation. He denies the propriety of naming these personalized, distinguishable potencies "persons." The personifications, for example, of the Spirit and of the Logos in the New Testament are religious thought-forms, and are not to be taken as scientific definitions. All the traditional arguments to prove a trinality of persons in God either fail or, if they be regarded as succeeding, disprove monotheism. Nitzsch holds an immanent modal Trinity, whose religious import is known to us only in historical revelation.

Members of the critical school, such as Lipsius and Pfleiderer, also recognize an economic or revelation Trinity. In Lipsius its import is: (I) the eternal ground of salvation; (2) God's historically revealed saving purpose; (3) God's present abiding will of love. For Pfleiderer it denotes God's revelation of himself in creation, redemption, and sanctification, that is, a Trinity of function. All these authors repudiate the Nicene doctrine of "eternal generation," and of three proper persons, and find the primary meaning of the trinitarian formula in the fact that it summarizes the three chief aspects of God's being and working known to us in revelation and redemption. 
As following a similar line of thought, I will instance two English-speaking writers - one British, one American-Mr. Walker, author of The Spirit and the Incarnation, and Professor King, of Oberlin, author of Reconstruction in Theology.

In discussing the Trinity and Unity of God, Mr. Walker refers to the difficulty which many find in the ordinary formulations of the Trinity involving, by its assertion of the eternal existence of three personalities, "plain tritheism." Then he adds: "It is now generally acknowledged that the Trinity of the New Testament is not, in itself, the ontological one of speculative theology, but the practical or economical one of God, the Father, revealed in Jesus Christ, his Son, and present in the Holy Spirit." Walker is ready to assert "distinctions" in God-three principles, but not three persons. Hence he claims that the pre-existence of Christ cannot be conceived as the eternal being, alongside of God, of a second personality. That would mean two eternal personal Gods. The Logos must be conceived as a principle or potency - God in his outgoing, self-imparting nature - the moving principle of creation, revelation, and redemption.

As Professor King expresses himself concisely on our subject, I will quote his words in full:

It can be no service to the church to react toward a really metaphysical tritheism, affirming social relations and love within the Godhead, in the immanent Trinity. The attempt has been widely approved, but I cannot doubt that, so far as it becomes a living faith, it means tritheism pure and simple, and will surely bring its own punishment. It seems probable that this attempt has come from a sincere desire to give Christ his true glory. But it has virtually proceeded, nevertheless, upon the wholly unwarranted assumption that the relations of Christ to God, whether on earth or in his preexistence or in his exaltation, were to be transferred forthwith to the relations of the immanent Trinity - to the inner relations of the very being of God himself.

This, at least, is true : nothing calls for more absolute and complete personality than love and social relations. To affirm social relations, therefore, in the Godhead is to assert absolute tritheism, and no plausible manipulation of the terms can avoid it. The analysis of self-consciousness, also, taken from Hegel, it seems to the writer - to put it flatly - helps not at all to a real Trinity, and proves nothing. It is far better that we should admit that we simply do not understand the eternal Trinity, than that, by explanations 
which do not explain, we should be driven to ascribe three persons to God in the only sense in which we can understand person, and not: be able to say that God is one person in any sense we can understand. This new tritheism seems to me less defensible than even the oldest credal statements of the Trinity, for those were at least scrupulously careful to insist that the distinctions in the Godhead were not personal, but that God was in truth one. ${ }^{2}$

We are likely to find the biblical doctrine of the Trinity more satisfying, both intellectually and religiously, than any later abstractly wrought out statements. We believe in one God, our Father, concretely and supremely revealed and brought nigh with absolute abiding assurance in Christ, and making himself known in the hearts of all who will receive him, in the most intimate, constant, and powerful, but not obtrusive, friendship possible to man, giving thus the supreme conditions of both character and happiness. This is the great practical New Testament confession of faith, contained both in the apostolic benediction and in the baptismal formula. (Reconstruction in Theology, pp. 191-3.)

It will be sufficiently apparent, I think, that all these theologians are pursuing essentially the same track of thought as that followed by Bushnell. The New England theology of his time was plainly tritheistic. Emmons did not hesitate to declare that the doctrine of the Trinity was perfectly clear and plain; the mystery was how God, being three persons, could be one God. ${ }^{3}$ The history of theology shows a constant oscillation between tritheism and some form of modal or revelation Trinity. Bushnell reacted from the former to the latter point of view, as modern theology has done. If there is any definable position

2 Did not the Athanasian theology hold a Trinity of three proper persons, saving the unity of God by a doctrine of eternal derivation and subordination? It was a later formulation, e.g., in Augustine, which affirmed the equality of the three, and hence was driven to save the unity of God by reducing the "persons" to modes or forms - indefinite and indefinable. "While the eastern theology (as represented in the creeds of Nicæa and Constantinople) insisted on the consubstantiality of the Son, there was always recognized the subordination of the second and third persons. In the Deity the Father is the beginning; it is to him that primal causality belongs. From the outset the West clung to the unity of substance, fastening attention on this cardinal element of the doctrine. It was through Augustine that, in the West, subordinationism was eliminated trom the trinitarian conception" (FISHER, History of Doctrine, p. 146).

3"We find no difficulty in conceiving of three divine persons. It is just as easy to conceive of three divine persons as of three human persons. . . . The only difficulty in this case lies in conceiving these three persons to be one." (Works, Vol. IV, p. III.) 
between these two views, religious thought has never found it or been able to stay in it. In a few translated passages from German theologians, especially from Twesten, Bushnell found illustrated another method of thought than that which was common on the subject, and he gladly welcomed it as an encouragement in his own struggles of mind. His practical result is well expressed in his phrase : a Trinity in act, that is, a Trinity seen and known in revelation, not in speculation. He saw in the Athanasian terms "eternal generation" and "procession" the idea of a Trinity in act, a Trinity becoming, as opposed to the notion of a static Trinity. He rejoiced to find this affinity (as he conceived it) between his views and the Nicene creed. But the resemblance was more apparent than real, and he never actually accepted the Nicene metaphysics of deity. His Trinity was a Trinity of revelation. He was ready to believe that the threefold revelation corresponded to the nature of God-each term, Father, Son, and Spirit, representing a real aspect of God. But what was the nature of that immanent threeness he could not define; nor did he believe that any man could define it. The current view was tritheism, if "person" means what "person" always means; if it does not really mean "person," then what does it mean? Distinction, function, aspect, mode, principle, potency. But all these are as indefinite as Bushnell's own doctrine, which was that the Trinity was an "instrumental verity"a summary of the great aspects of the Christian revelation. So far the New Testament goes; so far we may go, and no farther.

Bushnell's positive view of Christ and of the limits of our knowledge concerning him may be given very briefly. Christ was "the manifestation of the life of God ;" "he differs from us, not in degree, but in kind;" "he is God manifested;" he possesses a "superhuman quality," for he is absolutely unique and cannot be classed with other men. "In fact," adds Bushnell, "his divinity was never seriously questioned until after the easy and free representations of the Scripture and of the apostolic fathers had been hardened into dogma or converted, by the Nicene theologues and those of the subsequent ages, into a doctrine of the mere human understanding; an assertion of three 
metaphysical persons in the divine nature." Who, then, is Christ? $\mathrm{He}$ is "the incarnation of the divine nature," "the manifestation of God ;" "God was in Christ ;" etc. "Externally viewed, he is a union of God and man, whose object is to humanize the conception of God, and so to express or communicate God." If, now, one asks: "What are the contents of his person?" I answer that the question is impracticable, unphilosophic, dictated only by false curiosity, and, of course, not answered by Scripture. "Christ is not given as a riddle to our curiosity, or that we may set ourselves to reason out his mystery, but simply that God may thus express his own feeling and draw himself into union with us, by an act of accommodation to our human sympathie sand capacities" (God in Christ and Christ in Theology, passim).

These few quotations exhibit Bushnell's position as well as a hundred extracts would do. His conception involves two chief points: (I) the divinity of Christ is to be found in what he is and does for men as the Revealer of God and Savior from $\sin$; (2) the nature of the indwelling of God in him is a mystery on which theological metaphysics throws no light. I shall show, in some detail, that these are the chief points of the Ritschlian Christology.

In his treatise on The Ritschlian Theology, Garvie says :

If we endeavor to translate into current speech Ritschl's statements of the features in the revelation of God in Christ which warrant our assigning to him the predicate of divinity, we find that they are practically the evidences on which modern apologetics has been led to lay most stress. The essence of God as love is expressed in his person. $\mathrm{He}$ is in his teaching and work inexplicable by the world into which he came, and in his action and passion alike shows himself superior to it. He has been able to establish and maintain in that world a community, the members of which have his own filial consciousness of, and confidence in, God. There is an absolute identity between his activity and the fulfilment in the world of God's purpose for mankind. (P. 289.)

That this statement is true with respect to the present attitude of apologetics may be seen by reference to the treatise of Bruce, who says :

There is reason to believe that there now exists in many Christian minds a feeling of coldness, not to say aversion, to the definition of Christ's person 
handed down to us from ancient councils, as consisting of two distinct natures combined in the unity of a single personality (Apologetics, p. 399).

He predicts that the church of the future will recognize the futility of definite dogmatic solutions of the metaphysical problem of Christ's person. Where he finds the divineness of Jesus is evident from such words as these :

God is a Spirit, not merely ontologically, but ethically, and of what quality his Spirit is the man Jesus declares. God is love, and what divine love means the ministry of Jesus in life and death shows. God is good in the specific sense of being gracious, generous, philanthropic, and the historic life of Jesus interprets for us the philanthropy of God. All we really know of God in spirit and in very truth we know through Jesus. (Ibid., p. 350.)

The meaning of these statements is that it is not in the metaphysical, but in the ethical, categories that the Christian finds the divinity of Jesus. That was the great contention of Bushnell, and we shall see that it is the distinctive peculiarity of the theology of Ritschl.

Ritschl says: "According to the hints given us in the New Testament, the grace and truth manifested in his (Christ's) vocation, and the loftiness of his self-determination as compared with the particular and natural impulses which spring from the world, are the features in the earthly life of Christ which are summed up in the attribute of his Godhead" (Justification and Reconciliation, p. 463). Again he says: "Jesus experienced a relation to God which had not previously existed, and demonstrated it to his disciples; and it was his intention to introduce his disciples into the same religious view of the world and judgment of themselves, and under this condition into the universal task of the kingdom of God, which he knew to be assigned to his disciples as to himself." "New relation," "fresh estimate," "new task" - these are the distinctive marks of Christ for his followers; in these and such as these are found his religious value and power. In a word, his divinity is a name for his perfect revelation of God. He has the religious value of God to us, because in and through him God does interpret himself to men and save them. "Christ is God to us because he does for us what God alone can do" - is Garvie's summary of Ritschl's Christology. 
This Christian estimate of Christ is founded in history and in experience. It is a religious estimate - a value-judgment. The New Testament doctrine of Christ is of the same kind. Paul and John were not metaphysicians engaged in an effort to define the mystery of Christ's being; they were disciples who drew upon the available vocabulary of their age for means to set forth their conception and experience of the saving power of Christ as the mediator of the divine love and mercy. Paul's doctrine of the creatorship and world-ruling power of Christ is his way of setting forth the great Christian certainty that Christ represents and embodies God's eternal world-end. Christ's significance is the meaning and goal of the world. The pre-existence of Christ means that that which Christ historically reveals and accomplishes is grounded in God's eternal purpose of love. Most Ritschlians point to the fact that Jewish thought was wont to exalt the value of objects by conceiving them as pre-existing with God; hence the conception of Christ's pre-existence was a natural method of exalting his religious significance (see Harnack on the conception of pre-existence in his History of Dogma, Vol. I). It is pointed out that, if Christ's pre-existence is strictly taken as personal, it leads on to a Trinity of three metaphysical personalities, from which theology recedes as soon as it has established it.

The method of Ritschl in Christology, as of Bushnell, is historical and experimental. $\mathrm{He}$ repudiates the procedure of traditional theology as taking its start with the mysteries of the divine nature, instead of with a historical person. This involves theology in a maze of attempts to define and describe what no man has ever seen or known. We are entangled in definitions of natures and substances human and divine, and their combination, which explain not at all, to which no clear thought corresponds, and which are as incomprehensible as the original mystery. Orthodoxy tells us how an eternal divine person united with a human person to make a compound personality which was both man and God, both finite and infinite, both limited in knowledge and omniscient. Unable to square this description with history, kenoticism tells us that God veiled, 
disused, or even ceased to possess his divine attributes in the incarnation. The orthodoxy of Nicæa and Chalcedon Ritschl regards as the product of Greek speculation transforming the Christian gospel into an esoteric theosophy, while of the theory that an infinite being can by an act of will transform or diminish himself into finiteness he says: "This is nothing else but mythology."

Christ, then, is offered to our faith, not to our speculative understanding. These are the marks of his divinity: his perfect revelation of God's love; making his end the same as that of God; his dominion over the world; his founding and fostering of the kingdom of the God-like on earth. Both the positive and the negative aspects of Ritschl's view are stated in Dr. Somerville's summary of his Christology :

The predicate of Godhead, applied to Christ, is exhausted, Ritschl held, when we have recognized Him as the Revealer of God and the archetype of spiritual sovereignty over the world. The question of how he stands, in that relation, to God and to us is set aside as an idle one, as lying outside the limits of knowledge. (St. Paul's Conception of Christ, p. 317.)

His divinity is not to be sought, according to this view, in the vague, metaphysical categories, but in the moral and religious categories. Not "substance," "nature," and "subsistence," but "love," "moral triumph," and "forgiveness," express the Christian's sense of the value of Christ. Such is the view of the Ritschlians, and such, if I read him aright, was the view of Bushnell. Both placed a low estimate upon the creedal definitions of Christ's person, regarding them as going quite beyond Scripture warrant and as seeking to solve the insoluble, and, of course, conspicuously failing. Both exalted Christ as known in history and in experience. Both advocated a religious estimate of Christ and depreciated the subtleties of Greek speculation as an aid to faith. "Christ is here to express God, not to puzzle us in questions about the internal composition of his person," said Bushnell. There could be no better summation of the Ritschlian Christology.

In the doctrine of atonement the resemblance between Bushnell and Ritschl is less apparent. They are rooted, however, in 
similar general principles. The title of Bushnell's treatise on the subject discloses his point of view: The Vicarious Sacrifice, Grounded in Principles of Universal Obligation. His object was to translate the doctrine out of the language of physical, commercial, and legal analogy, into the language of religion and morality - to state the doctrine of salvation in terms of personal relation. His great principle was: the vicariousness of the divine love. God enters by sympathy into the suffering lot of his creatures and makes their woes and burdens his own. This revelation of the pitying love of God is adapted, as nothing else is, to soften human hearts and to lead men by repentance to become reconciled to God. It is, above all things, the goodness of God, as supremely revealed in Christ, which leads men to repentance. As for the sacrificial terms of Scripture, "priesthood," "propitiation," "blood," etc., they are figures of speech derived from the Jewish religion, necessary at the time to make real to men the saving power of Christ's life and death, and necessary still, but not to be regarded as adequately defining the inner spiritual meaning of Christ's saving work, but as symbols and analogies - pictorial representations of truths which are really moral and spiritual.

Bushnell thus rejected the penal-satisfaction theory current in his time. Nor did he regard with much greater favor the governmental view which was coming into vogue. His was an ethical interpretation which regarded the subject from the standpoint of the Christian's consciousness of the saving benefits of Christ, and not a theoretic construction based upon a priori definitions and a consequent dialetic. Bushnell built, as Ritschl did, on the love of God, though in a much less one-sided way than Ritschl. It is often represented that there was, according to the theory of Bushnell, no expression of the righteousness of God - the self-preservative, self-respecting quality of his nature - in the work of Christ, as if he had conceived the work of Christ as a revelation of the benevolence of God only. This is quite incorrect. In Forgiveness and Law, indeed, he approximated the current orthodoxy so far as to speak of God as propitiating himself in forgiveness, and declared that Dr. Shedd was right when 
he spoke of God as laying his wrath upon himself. In his efforts to find common ground with his critics, he says that by the work of Christ forgiveness is made compatible with the integrity and authority of the divine law, that Christ suffered in our place and as a propitiation for our sins. He was not unwilling to use the terms of current orthodoxy, but it was felt by his opponents - and doubtless correctly - that his meaning was different from theirs. He had his own view of the nature of such language. To him such terms were hints, figures, suggestions. To them they were scientific definitions. On the same principle, he declared that he would subscribe all the creeds. He could accept them as human thought-forms, earthen vessels in which men were trying to preserve the treasure of spiritual truth.

But it seems to me that we come closest to Bushnell's real thought and find its most characteristic expression neither in the polemic nor in the irenic parts of his writings, but in those parts in which he is spontaneously and constructively developing his thought in a free way. Where he is defining his views over against opinions which he repudiated he often overshoots the mark, and when he is trying to compromise with current orthodoxy, you feel that the approximation is rather apparent than real; that the identity is more in words than in thought. It was creditable to him that he sought common ground with his critics - and there was common ground. But it did not exist in the same method of thought or in the same understanding of terms, but in religious experience. The Christian life was essentially the same in all, but his thought and that of his age went wide asunder. No agreement in words could hide the underlying difference.

That Bushnell recognized in his own way the revelation, in the work of Christ, of the righteousness of God, and so maintained that in the death of Christ we see expressed at once "the goodness and the severity of God," is evident from expressions like these :

It is a fundamental condition, as regards moral effect on our character, that, while courage and hope are given us, we should be made, at the same time, to feel the intensest possible sense of the sanctity of the law and the 
inflexible righteousness of God. What we need in this view is some new expression of God, which, taken as addressed to us, will keep alive the impression in us that God suffers no laxity. In a word, we must be made to feel in the very article of forgiveness, when it is offered, the essential and eternal sanctity of God's law - his own immovable adherence to it - as the only basis of order and well-being in the universe. (God in Christ, p. 218.)

In order to make men penitent, and so to want forgiveness - that is, to keep the world alive to the eternal integrity, verity, and sanctity of God's law ; that is, to keep us apprised of sin, and deny us any power of rest while we continue under sin - it was needful that Christ, in his life and sufferings, should consecrate and re-consecrate the desecrated law of God, and give it a more exact and imminent authority than it had before." (P. 2I9.)

Bushnell specifies four ways in which Christ "brought the law closer to men's souls and gave it even a more sacred rigor and verity than it had before his advent ":

I. By his teaching concerning God's holy requirements.

2. By his own perfect obedience to the law of God.

3. By undergoing whatever sufferings were necessary in the effort " to re-establish the law as a living power in man's heart."

4. By his death, in which he asserts the sanctity of God's law - for thereby he will show us how much he is willing to endure in order to re-sanctify the law and renew us in the spirit of it.

In Bushnell's view the work of Christ was the fullest historic expression of the total nature of God. It was not a mere human example; it was a disclosure of God. His contention was the same as that of Maurice: the tragic experience of Jesus Christ on earth "meant the deliberate unfolding of the nature and life of God with such power and passion as to inspire in man a transforming trust and a uniting love" (R. H. Hutton).

Like Bushnell, Ritschl repudiates the penal conception of Christ's sufferings, and declares that his priesthood consists in his maintenance of his perfectly normal relation to God, and in his introduction of others into that same relation. This he does by founding the kingdom of God, in the life of which the Christian salvation is realized. Bushnell's view of salvation is more individualistic ; Ritschl's more social.

As related to the ethical nature of God, Ritschl regards the saving work of Christ as a disclosure of the divine love. In his 
view the wrath of God is an eschatological conception. Men become objects of God's wrath only in case of persistent and final impenitence. They are not here and now the objects of God's wrath, but only of his love. Ritschl has also an unusual conception of God's righteousness. It is a name for God's persistent purpose of grace; it designates the consistency with which God adheres to his determination to bless and save men in and through his kingdom. It denotes, not so much an aspect of God's nature, as an aspect of his method. It is not static, but dynamic.

In this view there is no possibility of setting love and righteousness in conflict, rivalry, or even contrast. The old conception of a satisfaction to righteousness wrought by love, through the death of Christ, is quite excluded. Even the simultaneous satisfaction of righteousness and love - of God's holy displeasure toward sin and his gracious feeling toward the sinner-as commonly conceived, has no place in Ritschl's system. Righteousness is satisfied only in the sense that God consistently pursues his loving purpose. That is righteousness. The difference between love and righteousness is purely formal. Righteousness is love moving ever onward, through all the ages and in the face of all hindrances, accomplishing its ends in making God known and in drawing men into fellowship with him in his kingdom.

Thus Ritschl departs much farther from traditional views than Bushnell. The latter ethicized the doctrine of atonement by taking it out of the world of figure and analogy, and by protesting against what seemed to him un-Christian views of God; but he still regarded righteousness as a constitutive factor in the being of God, and sought to show how it was expressed and satisfied in the work of Christ. I am confident that the views of Bushnell on this point correspond much more closely with the New Testament representations than do those of Ritschl. But space is wanting in which to enter into further criticism. The two theories are alike in this, that they aim to interpret the work of Christ in terms of ethics and personality, that is, to keep it in the world to which it belongs, and, further, to do this 
by building upon the Christian's experience of the saving power of Christ.

I have thus sought to set forth in outline the theories of Bushnell in the light of present-day theological thinking. No one who attends to the subject can doubt the resemblance between him and Ritschl, whatever may be his estimate of them. In the foregoing observations I have attempted an exposition, not a critique. I cannot, however, refrain from indicating, in closing, three points in which the theological movements which I have sketched have been of signal service to Christian thought and life :

I. In forcing the closest consideration of the nature and limits of theological knowledge. Theology has been compelled to tell us how it knows what it affirms.

2. In exposing the unclearness and the contradictions which abound in theology on the subject of the Trinity. How almost universal has it been to juggle with the word "person"! In almost any theological book in which the traditional formula "three persons in one God" is defended you can read arguments which prove tritheism, if they prove anything-arguments from the pre-existence passages and from social relations in God-a conclusion which is no sooner established than it is repudiated by the admission that "person" does not mean what "person" always means. Modern thought insists on clearness and consistency, and declines to affirm what it must confess in the next breath to be either contradictory or without apprehensible meaning.

3. The insistence that theology is not a kind of dialectic, proceeding from a priori premises-a play of the speculative intellect-but the science of the Christian faith, an interpretation of religion. It must, therefore, be understood and expressed according to its true nature. Above all must Christian theology be built up in accord with that concept of God which was fundamental in the consciousness of Jesus and central in his teaching. Only when theology is so constructed is it really Christian. Has this always been the case in the past? Are there not great creeds, purporting to be Christian confessions 
of faith, which do not even recognize the fatherhood of God, and not only have no word to say concerning his universal love for mankind, but logically quite exclude such an idea? It is an interesting subject for inquiry, which I can only suggest here, to what an extent our old Protestant theology was built upon specifically Jewish, as opposed to Christian, conceptions of God. God's partiality, his arbitrary election of some, the legal view of his relations to men and of his provision for salvationdo not these savor strongly of the late Jewish theology, and where do they find any warrant in the teaching of Jesus? I say deliberately that to me the old theology seems more Jewish than Christian. So far as it was biblical, its kinship was with the Old Testament and with certain traces of rabbinism which survived in Paul, rather than with the spirit and teaching of Jesus. The true task of our time is to Christianize theology to reconstruct it into accord with that highest revelation of the mind and will of God which is given in Jesus Christ. To this task no man among us has given a greater impulse than Horace Bushnell. I have sought to show that the thought of our own day is taking up this task and, in no small degree, working it out on the lines struck out by him. 